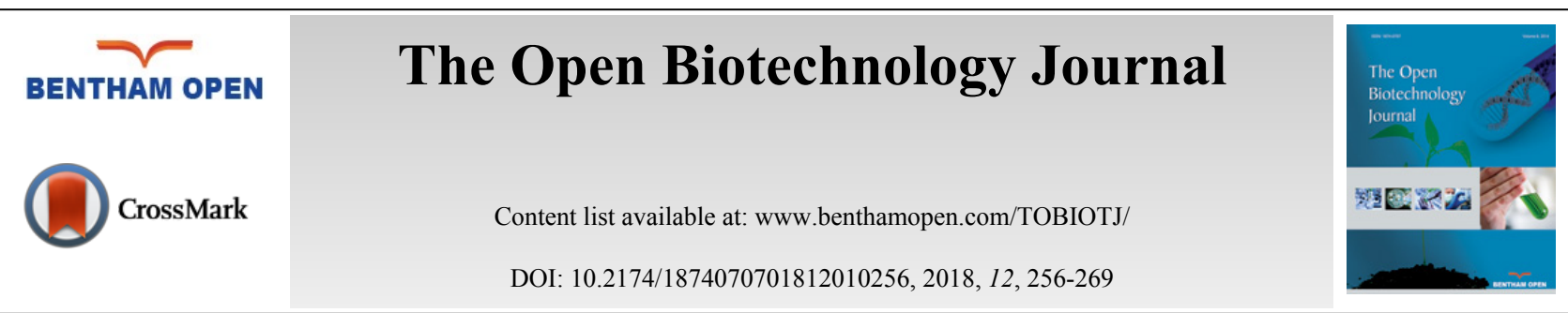

RESEARCH ARTICLE

\title{
Optimization of Cellulase Production by Aspergillus niger Isolated from Forest Soil
}

\author{
Srilakshmi Akula and Narasimha Golla* \\ Applied Microbiology Laboratory, Department of Virology, Sri Venkateswara University, Tirupati-517502 Andhra \\ Pradesh, India
}

Received: April 19, 2018

Revised: September 14, 2018

Accepted: September 25, 2018

\begin{abstract}
:
Background:

An impressive increase in the application of cellulases in various fields over the last few decades demands extensive research in improving its quality and large-scale production. Therefore, the current investigation focuses on factors relevant for optimal production of cellulase by Aspergillus niger isolated from forest soil.
\end{abstract}

\section{Method:}

Throughout this study, the fungal strain Aspergillus niger was maintained under the submerged condition for a period of 7 days at $120 \mathrm{rpm}$ rotational speed. Various physical and chemical conditions were employed in examining their influence on cellulase production by the selected fungal strain. After appropriate incubation, culture filtrates were withdrawn and checked for FPase, CMCase, and $\beta$-D-glucosidase activities.

\section{Results:}

The optimum $\mathrm{pH}$ and temperature for cellulase production were found to be 5.0 and $32^{\circ} \mathrm{C}$, respectively. Among the various carbon sources tested in the present study, amendment of lactose in the medium yielded peak values of FPase (filter paperase) and CMCase (Carboxy-methyl cellulase) whereas fructose supported the higher titers of $\beta$-glucosidase. Among the nitrogen sources, profound FPase and CMCase activity were recorded when urea was used but higher $\beta$-glucosidase activity was noticed when yeast extract was added. Various natural lignocellulosic substrates like bagasse, coir, corncob, groundnut shells, litter, rice bran, rice husk, sawdust and wheat bran were tested to find out the induction of cellulase. Among the lignocelluloses, sawdust and litter served as good substrates for cellulase production by Aspergillus niger.

\section{Conclusion:}

In gist, the outcome of this study sheds light on the cellulolytic potentiality of the fungal strain Aspergillus niger promising in its future commercial applications which may be economically feasible.

Keywords: Forest soil, Aspergillus niger, Cellulase, Lignocelluloses, Optimization conditions, Fungal strain.

\section{INTRODUCTION}

Cellulose is the major skeletal component of the cell wall of green biomass found together with hemicelluloses, pectin and lignin $[1,2]$. Cellulose is the fibrous, insoluble, crystalline polysaccharide composed of repeating units of Dglucose that is cemented by $\beta$-1, 4-glucosidic bonds [3]. Cellulose-rich plant biomass is one of the expected renewable sources of fuel, animal feedstock and feed for chemical synthesis [4]. Nowadays, huge quantities of municipal, industrial and agriculture cellulose wastes have been aggregated or exploited inefficiently due to the drastically lifted

\footnotetext{
* Address correspondence to this author at the Department of Virology, Sri Venkateswara University, Tirupati-517502 Andhra Pradesh, India, Tel: 9849781818; E-mail: gnsimha123@rediffmail.com
} 
cost of their utilisation process [5]. In order to diminish food-feed-fuel conflicts, it is essential to assimilate all these kinds of bio-waste into biomass economy [6]. The rate of utilization of plant biomass is largely dependent on active soil mycoflora. Fungi effectively degrade cellulose, hemicellulose and lignin in plants by secreting a multifarious set of hydrolytic and oxidative enzymes [7, 8] being the hydrolyses (especially cellulase) the most abundant. Thus, scientists are studying fungi at the molecular level $[9,10]$ trying to discover cellulolytic fungi [11] and are developing mutant strains to enhance the production of cellulases [12].

At present, the production of cellulase has widely been studied in submerged culture processes, but the relatively high costs of enzyme production have hindered the industrial application of cellulose bioconversion [13]. Thus, the economics of cellulase production needs to be improved by reducing production cost or increasing the enzyme activities. Several kinds of research have shown that the production costs of cellulase are tightly associated with the productivity of enzyme producing microbial strain, the final activity in the fermentation broth and type of substrate used in the fermentation production of the enzyme [14 - 17]. Keeping the above observations into consideration, the present work focused on the optimization of process parameters for enhanced cellulose production by Aspergillus niger isolated from the forest soil.

\section{MATERIALS AND METHODS}

\subsection{Microbial Strain}

The fungal culture Aspergillus niger used in the present study was isolated from the forest soil [18].

\subsection{Fungus Cultivation for Spore Production and Inoculums Preparation}

The fungal inoculum density of $2 \times 10^{6}$ spores [19] was used for cellulase production by submerged fermentation method and quantification was carried out by enzyme assays such as Filter paper Endoglucanase and $\beta$-D-Glucosidase.

\subsection{Optimization and Experimental Design}

\subsubsection{Effect of Medium pH on Cellulose Production by Aspergillus niger}

Czapek-Dox medium (HIMEDIA) used in this method contained (g/l); sucrose $-30, \mathrm{NaNO}_{3}-2, \mathrm{~K}_{2} \mathrm{HPO}_{4}-1$, $\mathrm{MgSO}_{4}-0.05, \mathrm{KCl}-0.5, \mathrm{FeSO}_{4}-0.01$. Czapek-Dox liquid medium amended with $1 \%$ cellulose was adjusted to different $\mathrm{pH}$ ranges $(3,4,5,6,7 \& 8)$ and distributed in $250 \mathrm{ml}$ Erlenmeyer conical flasks. The flasks were sterilized, cooled and inoculated with the fungal spore suspension. The flasks were incubated at $32^{\circ} \mathrm{C}$ on a rotary shaker at 120 rpm for 7 days. After incubation, dry weight of fungal mass, protein content, reducing sugars and individual enzyme components of cellulase activity was determined.

\subsubsection{Influence of Temperature on Cellulase Production by Aspergillus niger}

To check the influence of temperature on cellulase production, the conical flasks containing fermentation medium supplemented with $1 \%$ cellulose ( $\mathrm{pH} 5.0)$ were incubated at different temperatures $\left(25,32\right.$ and $\left.40^{\circ} \mathrm{C}\right)$. The flasks were inoculated with fungal spores. After incubation, dry mass of fungal mat, the extracellular protein, total soluble sugar, and activity of total cellulase was determined.

\subsubsection{Effect of Carbon Source on Cellulase Production by Aspergillus niger}

To determine the effect of various carbon sources on cellulase production in the Czapek-Dox medium, various carbon sources at 1\% (W/V) level were used. Glucose, fructose, lactose, galactose, maltose, and CMC were separately added to different Erlenmeyer flasks containing $100 \mathrm{~mL}$ of Czapek-Dox medium, the $\mathrm{pH}$ was adjusted to 5.0. The flasks with cellulose amended medium without a carbon source served as a control. The flasks were autoclaved at $121^{\circ} \mathrm{C}, 15$ lb pressure for 15 minutes. After sterilization, the flasks were cooled and inoculated with the spore suspension of Aspergillus niger. The flasks were incubated at $32^{\circ} \mathrm{C}$ on the rotary shaker at $120 \mathrm{rpm}$ for 7 days. Then the contents of flasks were filtered through Whatman No. 1 filter paper. Biomass, the extracellular protein content, total soluble sugar, and the total cellulase activity were determined in the collected culture filtrate.

\subsubsection{Effect of Nitrogen Sources on Cellulose Production by Aspergillus niger}

To know the impact of nitrogen sources on cellulase production, Erlenmeyer conical flasks (250ml) containing 100 
$\mathrm{ml}$ of Czapek-Dox medium with $1 \%(\mathrm{~W} / \mathrm{V})$ cellulose were separately added with various nitrogen sources like peptone, yeast extract, $\mathrm{KNO}_{3},\left(\mathrm{NH}_{4}\right)_{2} \mathrm{SO}_{4}$ and urea at a concentration of $0.03 \%$. The flasks with cellulose amended medium without nitrogen source served as control. All the flasks were aseptically inoculated with spores of Aspergillus niger and the flasks were incubated at $32^{\circ} \mathrm{C}$ on a rotary shaker at $120 \mathrm{rpm}$ for 7 days. Biomass, extracellular protein content, glucose content and total cellulase activity were determined in the collected culture filtrate.

\subsubsection{Effect of Lignocellulosic Substrates on Cellulase Production by Aspergillus niger}

To detect the supportive native lignocellulosic substrates for the production of cellulase complex, different natural lignocellulosic substrates which include sawdust, rice bran, rice husk, wheat bran, bagasse, litter, groundnut shells, and coir and corn cob were used in the present study. $100 \mathrm{ml}$ of Czapek-Dox broth medium was distributed into separate Erlenmeyer conical flasks. Each flask was provided with one gram of finely powdered untreated lignocelluloses. The $\mathrm{pH}$ of the medium was adjusted to 5.0. After sterilization, the flasks were cooled and inoculated with the spore suspension of Aspergillus niger. The flasks were incubated at $32^{\circ} \mathrm{C}$ for 7 days on a rotary shaker at $120 \mathrm{rpm}$. After 7 days of incubation, the contents of the flasks were filtered through Whatman filter paper No. 1. The culture filtrates were used for the estimation of biomass, the extracellular protein content, total soluble sugar and total cellulase activities.

\subsection{Analytical Methods}

\subsubsection{Estimation of Protein Content}

The extracellular protein content in the fungal filtrate was determined [20]. Suitable aliquots of filtrate were mixed with $5 \mathrm{ml}$ of alkaline solution. After $30 \mathrm{~min}, 0.5 \mathrm{ml}$ Folin-Ciocalteu's - reagent was added. The color developed was read at $550 \mathrm{~nm}$ by using the spectrophotometer (Spectronic- 20D). Bovine serum albumin was used as a protein standard.

\subsubsection{Estimation of Sugar Content}

The total soluble sugar content in the culture filtrates was determined [21]. Glucose was used as a standard. Suitable aliquots of culture filtrates were mixed with $3 \mathrm{ml}$ of DNS reagent. The contents were boiled vigorously in a boiling water bath for exactly five minutes and the colour developed was read at $540 \mathrm{~nm}$ by using the spectrophotometer (Spectronic-20D).

\subsubsection{Determination of Fungal Biomass}

The fungal biomass was estimated by incubating the fungal culture for 7 days. After incubation, the contents of the flasks were aseptically passed through a pre-weighed filter paper (Whatman No.1) to separate mycelial mat from culture filtrate. The filter paper along with mycelial mat was dried at $70^{\circ} \mathrm{C}$ in an oven until constant weight and the weight was recorded. Difference between the weights of the filter paper bearing mycelial mat and weight of pre-weighed filter paper represented fungal biomass, which was expressed in terms of dry weight of mycelial mat (mg/100 ml of CzapekDox medium).

\subsubsection{Determination of Cellulase Activity}

The filtrates obtained after removal of mycelia mat by filtration through filter paper was used as an enzyme source. Flasks containing the growing culture of Aspergillus niger were withdrawn at every 7- day interval for processing.

\subsubsection{Determination of Filter Paper Assay (FPA)}

Filter paper activity of the culture filtrates was determined according to the method of Mandels and Weber (1969) [22]. Whatman filter paper strips containing $50 \mathrm{mg}$ weight was suspended in one $\mathrm{ml}$ of $0.05 \mathrm{M}$ sodium citrate buffer (pH 4.8) at $50^{\circ} \mathrm{C}$ in a water bath. Suitable aliquots of enzyme source were added to the above mixture and incubated for 60 minutes at $50^{\circ} \mathrm{C}$. After incubation, the liberated reducing sugars were estimated by the addition of 3 , 5Dinitrosalicylic acid [21]. After cooling, colour developed in tubes was read at $540 \mathrm{~nm}$ in a spectrophotometer (Spectronic-20D). Appropriate control without enzyme was simultaneously made to run. The activity of cellulase was expressed in filter paper units. One unit of Filter Paper Unit (FPU) was defined as the amount of enzyme releasing one micromole of reducing sugar from filter paper $/ \mathrm{ml} / \mathrm{h}$. 


\subsubsection{Determination of Endoglucanase Activity}

The activity of endoglucanase in the culture filtrate was quantified by carboxymethylcellulose method [23]. The reaction mixture with $1.0 \mathrm{ml}$ of $1 \%$ carboxymethyl cellulose in $0.2 \mathrm{M}$ acetate buffer $(\mathrm{pH} 5.0)$ was pre-incubated at $50^{\circ} \mathrm{C}$ in a water bath for 20 minutes. An aliquot of $0.5 \mathrm{ml}$ of culture filtrate with appropriate dilution was added to the reaction mixture and incubated at $50^{\circ} \mathrm{C}$ in a water bath for an hour. Appropriate control without enzyme was simultaneously made to run. The reducing sugar produced in the reaction mixture was determined by Dinitrosalicylic acid (DNS) method [21]. 3, 5-Dinitro-salicylic acid reagent was added to aliquots of the reaction mixture and the colour developed was read at a wavelength of $540 \mathrm{~nm}$ by using the spectrophotometer (Spectronic-20D). One unit of endoglucanase activity was defined as the amount of enzyme releasing one micromole of reducing sugar $/ \mathrm{ml} / \mathrm{h}$.

\subsubsection{Estimation of $\beta-D-G l u c o s i d a s e$ Activity}

The activity of $\beta$-glucosidase in the culture filtrates was determined based on the method of Herr (1979) [24]. 200 microlitres of $5 \mathrm{mM} p$-nitro phenyl $\beta$-D-glucopyranoside (PNPG,) in $0.05 \mathrm{M}$ citrate buffer $\mathrm{pH} 4.8$ was added to $0.2 \mathrm{ml}$ of diluted enzyme solution with appropriate controls. After incubation for $30 \mathrm{~min}$ at $50^{\circ} \mathrm{C}$, the reaction was stopped by adding $4 \mathrm{ml}$ of $0.05 \mathrm{M} \mathrm{NaOH}-\mathrm{Glycine}$ buffer $(\mathrm{pH} 10.6)$ and the liberated yellow colored $p$-nitrophenol was determined at $450 \mathrm{~nm}$ by using the spectrophotometer (Spectronic-20D). One unit of $\beta$-glucosidase activity was defined as the amount of enzyme liberating one micromole of $\mathrm{p}$-nitro phenol $/ \mathrm{ml} / \mathrm{h}$ under standard assay conditions.

\section{RESULTS}

\subsection{Fungal Culture}

The fungal culture Aspergillus niger used in this study was isolated from forest soil [18]. Similarly, Narasimha et al., [25] isolated and identified a potent cellulolytic fungi Aspergillus niger from soil contaminated with cotton ginning industry effluents.

\subsection{Optimization Conditions for Cellulase Production by Aspergillus niger}

A series of experiments were carried out to determine the factors for enhanced production of cellulase by Aspergillus niger.

\subsubsection{Effect of Medium pH}

The effect of different $\mathrm{pH}$ ranges (3-8) on cellulase production by Aspergillus niger was tested and listed (Figs. 1, 2 and Table 1). Though maximum growth $(1800 \mathrm{mg} / 100 \mathrm{ml}$ of Czapek-Dox medium) of tested organism was obtained at $\mathrm{pH} 4.0$, maximum activities of FPase $(14.16 \mathrm{U} / \mathrm{ml})$, CMCase $(64.00 \mathrm{U} / \mathrm{ml})$, extracellular protein $(1.65 \mathrm{mg} / \mathrm{ml})$, total soluble sugar $(7.11 \mathrm{mg} / \mathrm{ml})$ were recorded at $\mathrm{pH} 5.0$. Relatively lower activities of FPase $(0.38-1.6 \mathrm{U} / \mathrm{ml}), \mathrm{CMCase}$ $(8.11-10.2 \mathrm{U} / \mathrm{ml})$ and $\beta$-glucosidase $(0.006 \mathrm{U} / \mathrm{ml})$, lower amounts of total soluble sugar $(0.07-0.42 \mathrm{mg} / \mathrm{ml}), \mathrm{the}$ extracellular protein $(0.22-0.41 \mathrm{mg} / \mathrm{ml})$ was found when the culture was grown at $\mathrm{pH} 3.0,4.0$ and 8.0 . The less vegetative growth of $1460 \mathrm{mg} / 100 \mathrm{ml}$ was found at $\mathrm{pH}$ value of 8.0 . $\beta$-glucosidase activity was not detected when $\mathrm{pH}$ of the medium was set above 5.0. Thus, it was clear from the above results that $\mathrm{pH} 5.0$ was found to optimum $\mathrm{pH}$ value for cellulase production in case of Aspergillus niger.

Table 1. Effect of medium pH ranges on cellulase production.

\begin{tabular}{|c|c|c|c|c|}
\hline Sr. No. & Medium pH Range & $\underset{(\mathrm{U} / \mathrm{m} / \mathrm{h})}{\mathrm{FPase}^{\mathrm{a}}}$ & $\underset{(\mathrm{U} / \mathrm{m} / \mathrm{h})}{\mathrm{CMCase}^{\mathrm{b}}}$ & $\beta$-Glucosidase ${ }_{(\mathrm{U} / \mathrm{m} / \mathrm{h})}^{\mathrm{c}}$ \\
\hline 1. & 3 & 0.38 & 8.11 & ND \\
\hline 2. & 4 & 0.444 & 10.22 & 0.006 \\
\hline 3. & 5 & 14.16 & 64.00 & 0.014 \\
\hline 4. & 6 & 13.56 & 29.78 & ND \\
\hline 5 & 7 & 13.33 & 28.88 & $\mathrm{ND}$ \\
\hline 6. & 8 & 1.611 & 9.22 & ND \\
\hline
\end{tabular}

$\mathrm{ND}=$ Not detected, The results are the mean of three different experiments. 


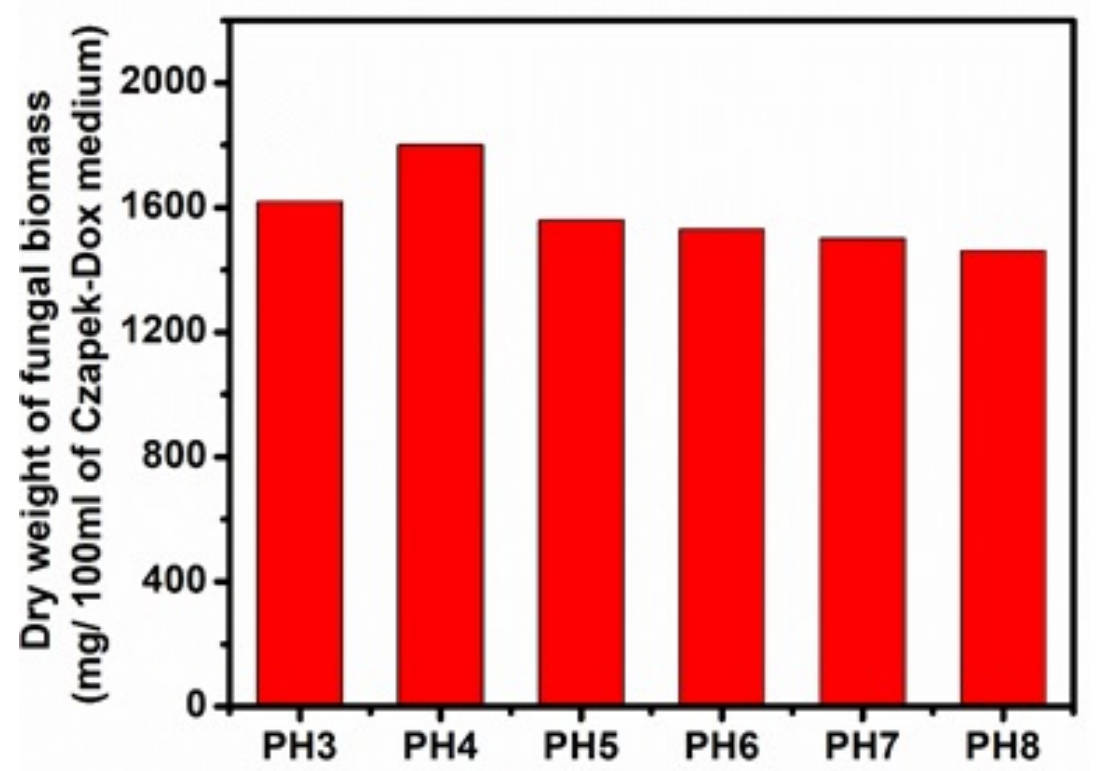

Fig. (1). Effect of different medium $\mathrm{pH}$ on $A$. niger biomass production. The results are the mean of three different experiments.

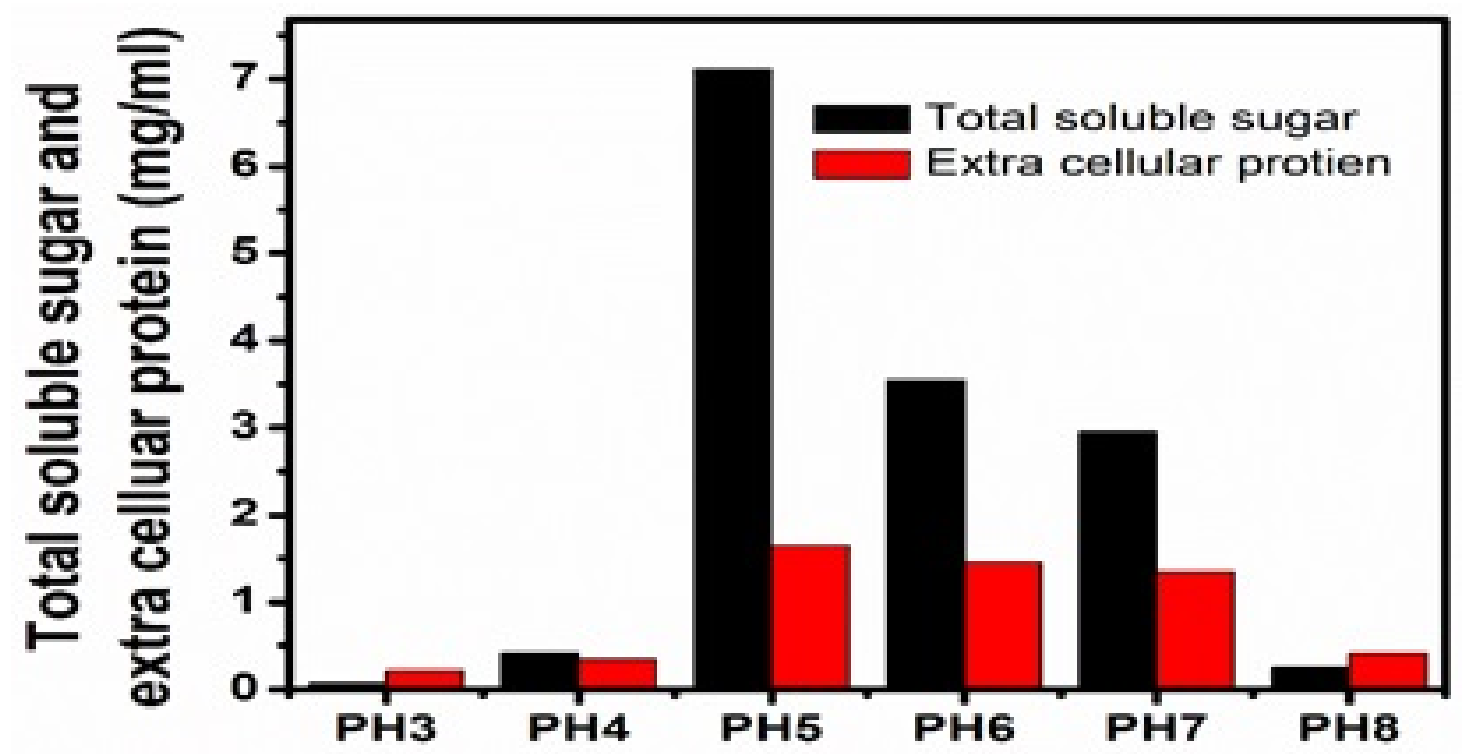

Fig. (2). Effect of medium $\mathrm{pH}$ on soluble sugar and protein production. The results are the mean of three different experiments.

\subsubsection{Effect of Temperature}

Temperature highly influences growth and enzymatic activities of microorganisms. The effect of different temperatures on cellulase production was studied and results were depicted in Figs. (3, 4 and Table 2). The culture filtrates obtained from the flasks incubated at $32^{\circ} \mathrm{C}$ exhibited higher of FPase activity (14.66 U/ml), CMCase (64.00 $\mathrm{U} / \mathrm{ml})$ and $\beta$-glucosidase $(0.014 \mathrm{U} / \mathrm{ml})$, fungal biomass of $1670 \mathrm{mg} / 100 \mathrm{ml}$ of Czapek-Dox medium, the extracellular protein of $1.65 \mathrm{mg} / \mathrm{ml}$ and total soluble sugar of $7.11 \mathrm{mg} / \mathrm{ml}$ (Figs. 10). Comparatively lower activities of FPase $(2.66 \mathrm{U} / \mathrm{ml})$, CMCase $(9.32 \mathrm{U} / \mathrm{ml})$ and $\beta$-glucosidase $(0.006 \mathrm{U} / \mathrm{ml})$ as well as lower contents of extracellular protein $(0.71 \mathrm{mg} / \mathrm{ml})$, total soluble sugar $(0.55 \mathrm{mg} / \mathrm{ml})$ and biomass of $(1480 \mathrm{mg} / 100 \mathrm{ml})$ were recorded at $40^{\circ} \mathrm{C}$. The culture filtrate obtained from the flask incubated at $25^{\circ} \mathrm{C}$ shows FPase of $7.62 \mathrm{U} / \mathrm{ml}$, CMCase of $30.88 \mathrm{U} / \mathrm{ml}$ and $\beta$-glucosidase of $0.006 \mathrm{U} / \mathrm{ml}$. The dry weight of fungal biomass was $1580 \mathrm{mg} / 100 \mathrm{ml}$, the extracellular protein was $1.58 \mathrm{mg} / \mathrm{ml}$ and total soluble sugar was $6.88 \mathrm{mg} / \mathrm{ml}$. These values lie in between the activity ranges of the above-discussed temperatures $\left(32^{\circ} \mathrm{C}, 40^{\circ} \mathrm{C}\right)$. 


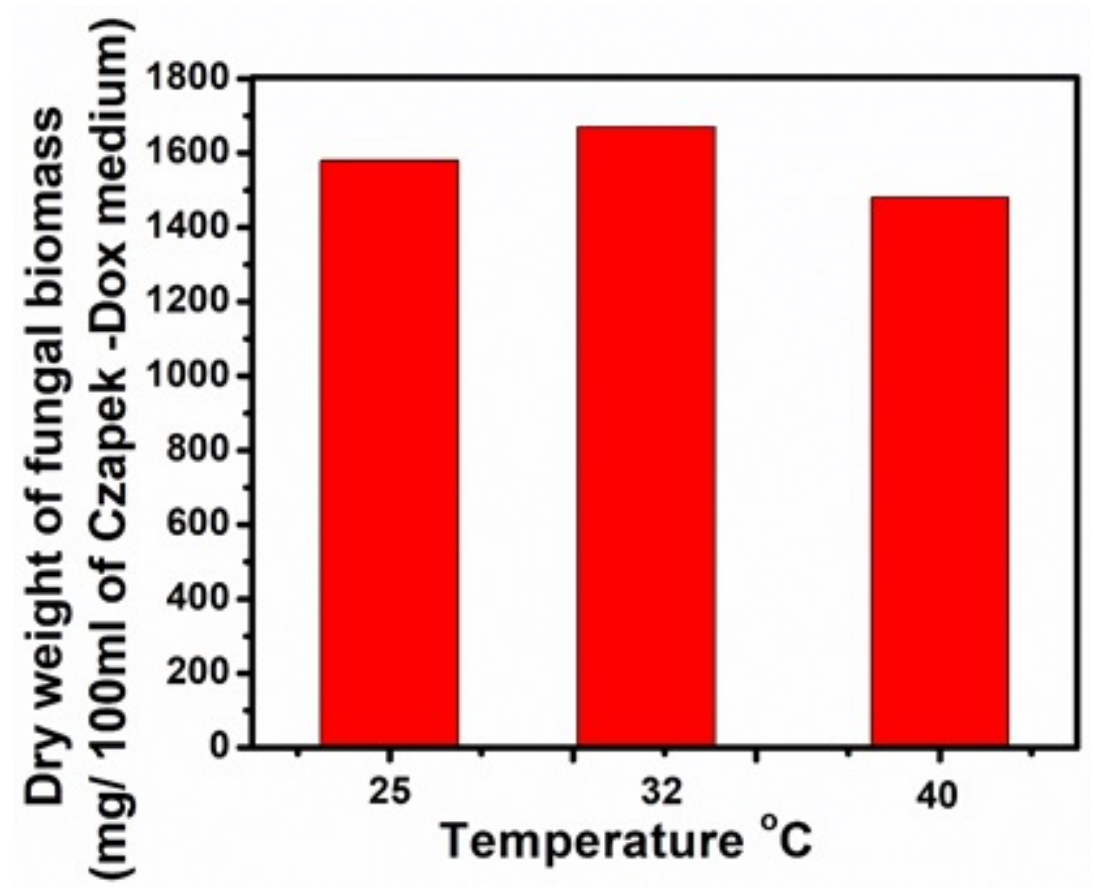

Fig. (3). Effects of temperature on biomass production.

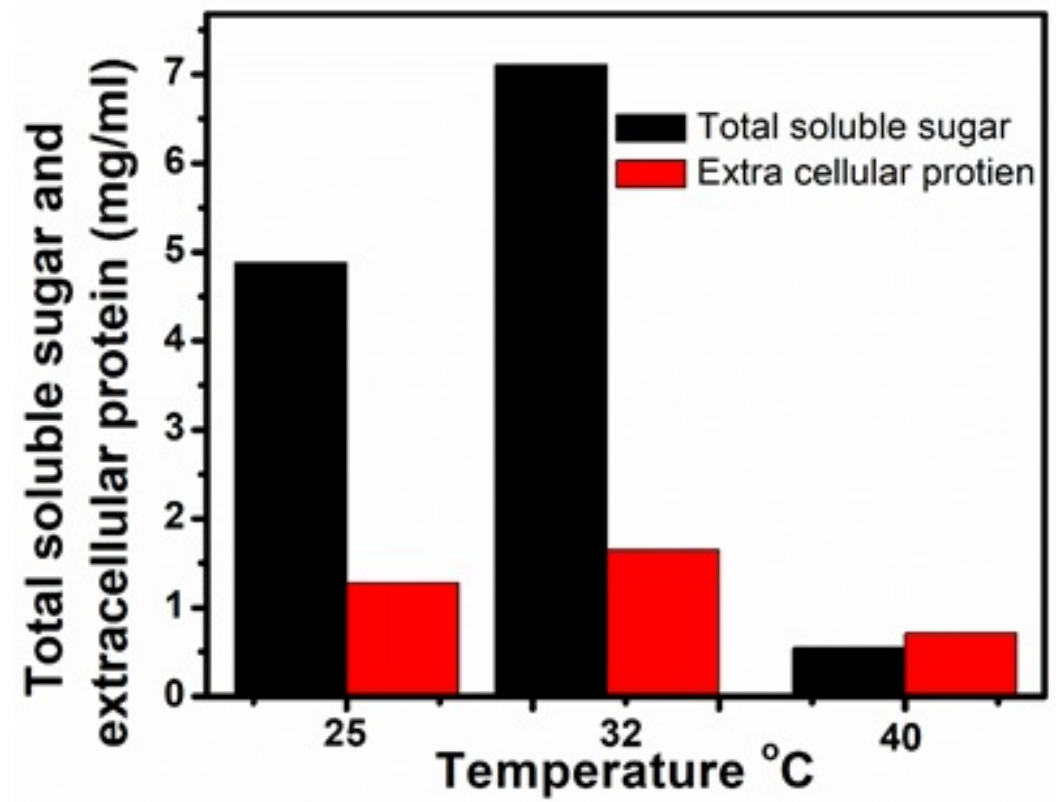

Fig. (4). Effects of temperature on total sugar and protein content. The results are the mean of three different experiments.

Table 2. Effect of various temperatures on cellulase production.

\begin{tabular}{|c|c|c|c|c|}
\hline Serial Number & $\begin{array}{c}\text { Temperature } \\
\left({ }^{\circ} \mathrm{C}\right) \\
\end{array}$ & $\begin{array}{c}\text { FPase }_{(\mathrm{U} / \mathrm{m} / \mathrm{h})} \\
\end{array}$ & $\underset{(\mathrm{U} / \mathrm{m} / \mathrm{h})}{\text { CMCa }^{\mathrm{b}}}$ & $\underset{(\mathrm{U} / \mathrm{m} / \mathrm{h})}{\beta \text {-Glucosidase }}{ }^{\mathrm{c}}$ \\
\hline 1. & 25 & 7.62 & 30.88 & 0.006 \\
\hline 2. & 32 & 14.66 & 64.00 & 0.014 \\
\hline 3. & 40 & 2.66 & 9.32 & 0.006 \\
\hline
\end{tabular}

$\mathrm{ND}=$ Not Detected. The results are the mean of three different experiments. 


\subsubsection{Effect of Carbon Sources}

Different carbon sources used in this study exhibited variable effects on the selected parameters (Figs. 5, 6 and Table 3). Of the carbon sources applied, lactose supported the maximal activities of FPase (38.33 U/ml) CMCase (85.54 $\mathrm{U} / \mathrm{ml})$, higher extracellular protein $(9.6 \mathrm{mg} / \mathrm{ml})$ and total soluble sugar $(9.6 \mathrm{mg} / \mathrm{ml})$. $\beta$-glucosidase activity was higher $(0.02 \mathrm{U} / \mathrm{ml})$ when fructose was used as carbon source. The inclusion of maltose and galactose exhibited higher titres of FPase and CMCase next to lactose. The relatively higher vegetative growth of Aspergillus niger of $3330 \mathrm{mg} / 100 \mathrm{ml}$ was obtained in the medium supplemented with carboxymethyl cellulose (CMCellulose) as substrate. The three enzyme components FPase $(4.33 \mathrm{U} / \mathrm{ml})$, CMCase $(16.11 \mathrm{U} / \mathrm{ml})$ and $\beta$-glucosidase $(0.007 \mathrm{U} / \mathrm{ml})$ were exhibited at low levels. The extracellular protein content $(0.77 \mathrm{mg} / \mathrm{ml})$ and total soluble sugar $(0.9 \mathrm{mg} / \mathrm{ml})$ were also recorded at lower levels in the Carboxymethylcellulose(CMCellulose) amended medium. Compared to remaining carbon sources used in the present study, FPase and CMCase activities in glucose and fructose amended medium were found to be intermediate to the above-described ones. $\beta$-glucosidase activity was not detected in the medium amended with glucose, lactose, and maltose.

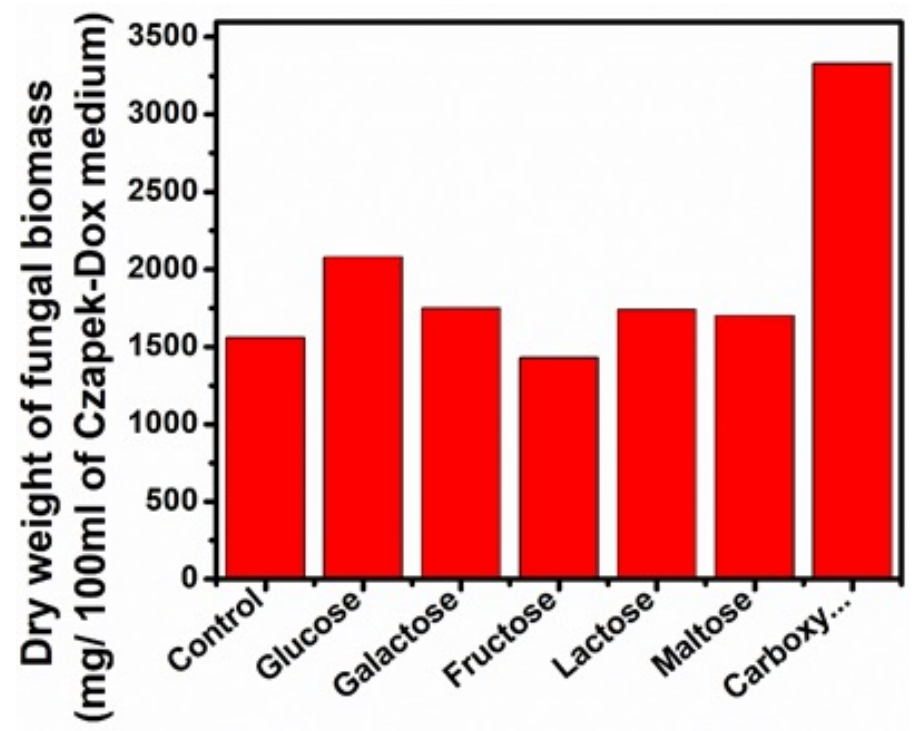

Fig. (5). Effect of carbon source on soluble sugar and protein content.

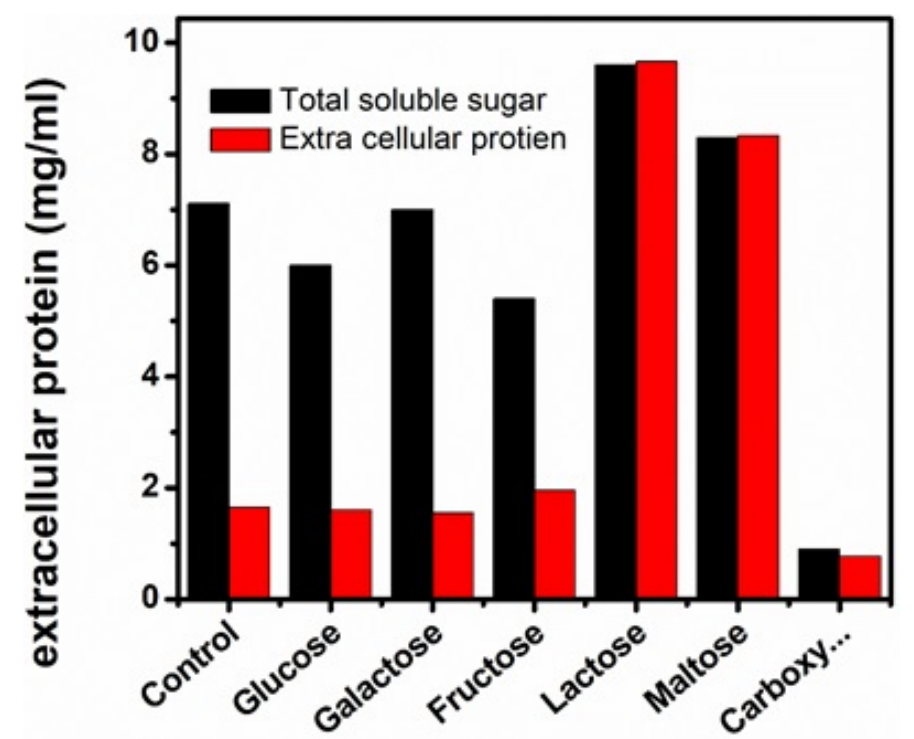

Fig. (6). Effect of carbon sources on biomass production. The results are the mean of three different experiments. 
Table 3. Effect of carbon sources on cellulase production.

\begin{tabular}{|c|c|c|c|c|}
\hline Serial Number & Carbon Source & $\underset{(\mathrm{U} / \mathrm{m} / \mathbf{h})}{\text { FPas }^{\mathbf{a}}}$ & $\underset{(\mathrm{U} / \mathrm{m} / \mathrm{h})}{\operatorname{CMCas}{ }^{b}}$ & $\beta-\underset{(\mathrm{U} / \mathrm{m} / \mathrm{h})}{\operatorname{siducosidas}} \mathrm{e}^{\mathrm{c}}$ \\
\hline 1. & Glucose & 26.38 & 47.76 & ND \\
\hline 2. & Galactose & 32.77 & 63.32 & 0.007 \\
\hline 3. & Fructose & 23.33 & 52.22 & 0.020 \\
\hline 4. & Lactose & 38.33 & 85.54 & ND \\
\hline 5 & Maltose & 37.77 & 77.76 & ND \\
\hline 6. & CMC & 4.33 & 16.11 & 0.007 \\
\hline 7. & Control $^{d}$ & 14.16 & 64.00 & 0.014 \\
\hline
\end{tabular}

$\mathrm{ND}=$ Not Detected. The results are the mean of three different experiments.

The results are the mean of three different experiments.

\subsubsection{Effect of Nitrogen Sources}

The effects of various nitrogen sources on cellulase production were studied and compared with control (Figs. 7, 8 and Table 4). Among the list of nitrogen sources, urea appeared to be the best as reflected by the highest production of extracellular protein $(210 \mathrm{mg} / \mathrm{ml}) .38 .88 \mathrm{U} / \mathrm{ml}$ of FPase, $68.88 \mathrm{U} / \mathrm{ml}$ of CMCase, and total soluble sugar of $8.70 \mathrm{mg} / \mathrm{ml}$. $\beta$-glucosidase was undetected not only in urea but also in peptone and $\mathrm{KNO}_{3}$ amended medium. Though higher $\beta$ glucosidase activity $(0.230 \mathrm{U} / \mathrm{ml})$ was observed in yeast extract supplemented medium lower activities of FPase $(0.77$ $\mathrm{U} / \mathrm{ml})$, CMCase $(7.32 \mathrm{U} / \mathrm{ml})$ was recorded. Maximum $(2080 \mathrm{mg} / 100 \mathrm{ml})$ and minimum $(1490 \mathrm{mg} / 100 \mathrm{ml})$ fungal growth were observed in $\left(\mathrm{NH}_{4}\right)_{2}, \mathrm{SO}_{4}$ and $\mathrm{KNO}_{3}$ amended medium, respectively. Considerably lower activities of FPase and CMCase along with lower amounts of extracellular protein and total soluble sugar yeast extract and $\left(\mathrm{NH}_{4}\right)_{2}$, $\mathrm{SO}_{4}$ supplemented medium.

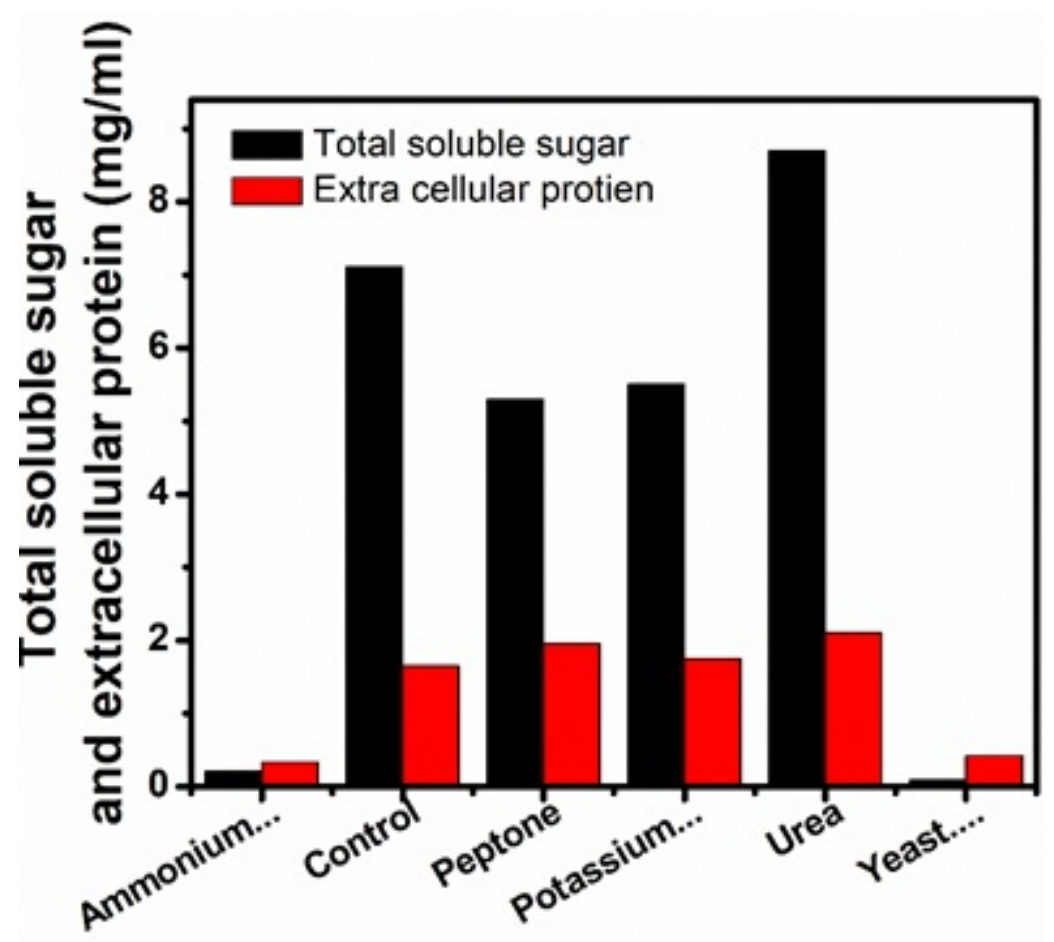

Fig. (7). Effect of nitrogen sources on soluble sugar and protein content. 


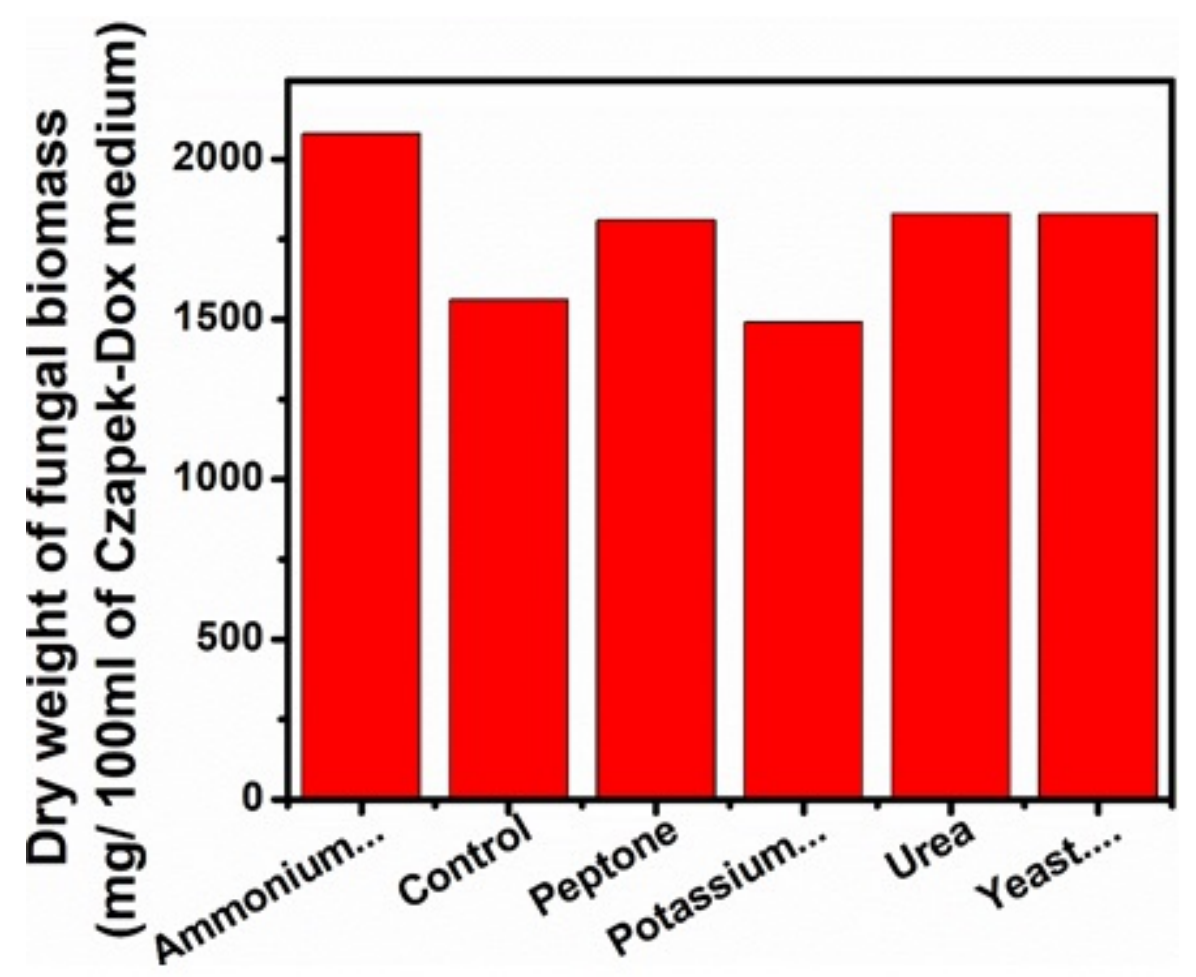

Fig. (8). Effect of nitrogen source on biomass production. The results are the mean of three different experiments.

Table 4. Effect of carbon sources on cellulase production.

\begin{tabular}{|c|c|c|c|c|}
\hline Serial Number & Carbon Source & $\underset{(\mathrm{U} / \mathrm{m} / \mathrm{h})}{\text { FPase }^{\mathrm{a}}}$ & $\underset{(\mathrm{U} / \mathrm{m} / \mathrm{h})}{\mathrm{CMCas}^{\mathrm{b}}}$ & $\beta$-glucosidase ${ }_{(\mathrm{U} / \mathrm{m} / \mathrm{h})}^{\mathrm{c}}$ \\
\hline 1. & Glucose & 26.38 & 47.76 & ND \\
\hline 2. & Galactose & 32.77 & 63.32 & 0.007 \\
\hline 3. & Fructose & 23.33 & 52.22 & 0.020 \\
\hline \multirow[t]{2}{*}{4.} & Lactose & 38.33 & 85.54 & ND \\
\hline & Maltose & 37.77 & 77.76 & ND \\
\hline 6. & CMC & 4.33 & 16.11 & 0.007 \\
\hline 7. & Control $^{\mathrm{d}}$ & 14.16 & 64.00 & 0.014 \\
\hline
\end{tabular}

$\mathrm{ND}=$ Not detected .The results are the mean of three different experiments.

\subsection{Effect of Lignocellulosic Substrates}

Various natural lignocelluloses were employed at 1\% level in Czapek-Dox medium to induce cellulase production by Aspergillus niger. The results were compared to the yields of cellulase synthesized by the same microorganism on cellulose (Figs. 9, 10, Table 5). Among the lignocelluloses supplemented in the present study, the sawdust induced maximum biomass of $1650 \mathrm{mg} / 100 \mathrm{ml}$, the total soluble sugar of $7.90 \mathrm{mg} / \mathrm{ml}$ and the highest titres of FPase (31.11 $\mathrm{U} / \mathrm{ml}) \mathrm{CMCase}(67.54 \mathrm{U} / \mathrm{ml})$ and lower yields of extracellular protein $(1.71 \mathrm{mg} / \mathrm{ml})$ were noticed. Higher quantities of $\beta$-glucosidase $(0.43 \mathrm{U} / \mathrm{ml})$ were obtained with bagasse. Supplementation of forest litter induced the yields of FPase (29 $\mathrm{U} / \mathrm{ml})$ CMCase $(60.44 \mathrm{U} / \mathrm{ml})$, total soluble sugar $(5.0 \mathrm{mg} / \mathrm{ml})$ which proved it as a good inducer of cellulase production next to sawdust. The secretion of extracellular protein was maximum $(1710 \mathrm{mg} / \mathrm{ml})$ when groundnut shells were added as substrate. The decreased activities of FPase and CMCase were noticed with rice bran, groundnut shells, wheat bran, and bagasse. The lowest $\beta$-glucosidase activity $(0.02 \mathrm{U} / \mathrm{ml})$ was recorded in wheat bran and groundnut shells. Least values of total soluble sugar $(0.87 \mathrm{mg} / \mathrm{ml})$, extracellular protein $(0.75 \mathrm{mg} / \mathrm{ml})$ and dry weight $(690 \mathrm{mg} / 100 \mathrm{ml}) \mathrm{were}$ noticed in the experiments which used bagasse as a substrate. 


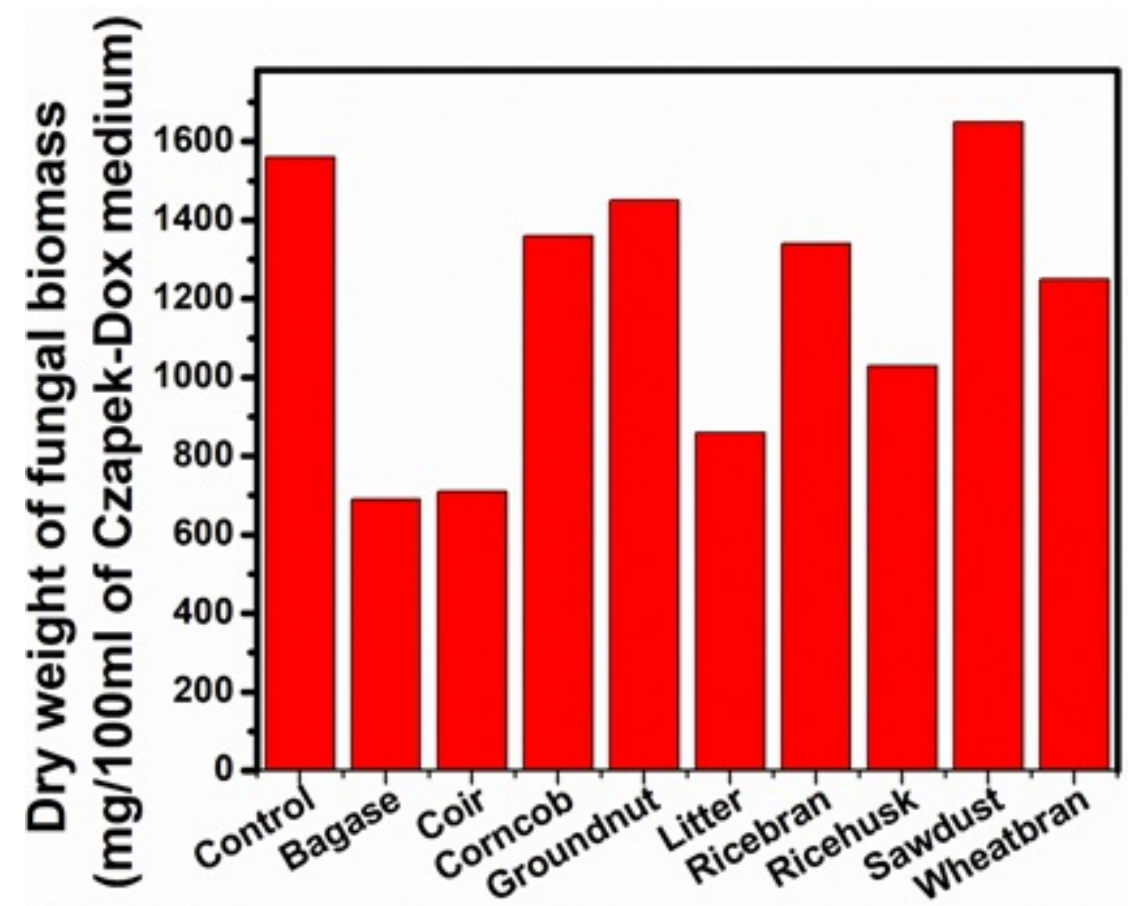

Fig. (9). Effect of lignocelluloses on biomass production.

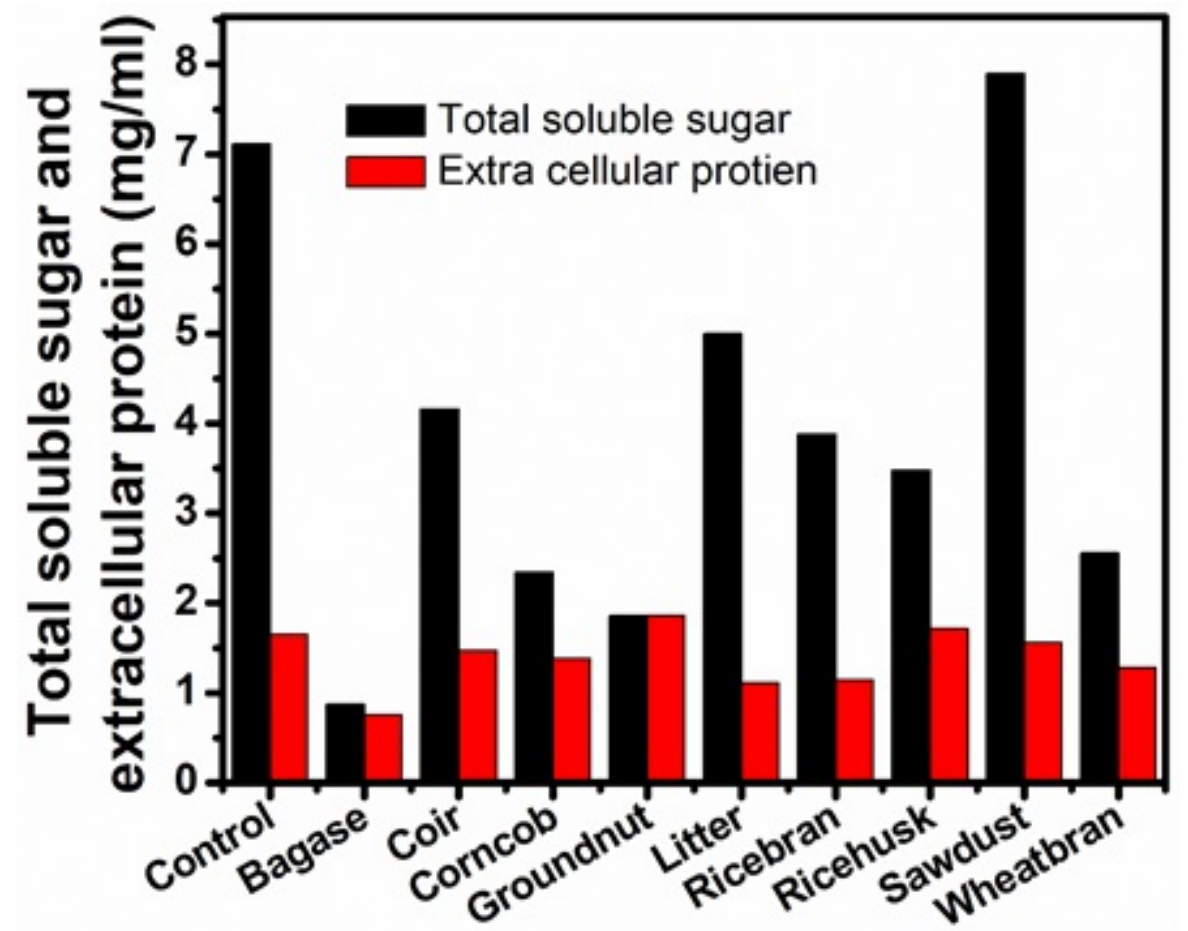

Fig. (10). Effect of lignocelluloses on soluble sugar and protein content. The results are the mean of three different experiments.

Table 5. Influence of Lignocellulosic substrates for cellulase production.

\begin{tabular}{|c|c|c|c|c|}
\hline Serial Number & Lignocellulose & $\underset{(\mathrm{U} / \mathrm{m} / \mathrm{h})}{\mathrm{FPase}^{\mathrm{a}}}$ & $\underset{(\mathrm{U} / \mathrm{m} / \mathrm{h})}{\mathrm{CMCase}^{\mathrm{b}}}$ & $\beta$-Glucosidase ${ }_{(\mathrm{U} / \mathrm{m} / \mathrm{h})}^{\mathrm{c}}$ \\
\hline 1. & Bagasse & 3.5 & 8.88 & 0.43 \\
\hline
\end{tabular}




\begin{tabular}{|c|c|c|c|c|}
\hline Serial Number & Lignocellulose & $\underset{(\mathrm{U} / \mathrm{ml} / \mathrm{h})}{\mathrm{FPase}^{\mathrm{a}}}$ & $\underset{(U / m / / h)}{\text { CMCase }^{b}}$ & $\beta$-Glucosidase ${ }_{(\mathrm{U} / \mathrm{m} / \mathrm{h})}^{\mathrm{c}}$ \\
\hline 2. & Coir & 19.55 & 21.32 & 0.05 \\
\hline 3. & Corncob & 15.33 & 28.44 & 0.32 \\
\hline 4. & Groundnut shells & 8.50 & 11.66 & 0.02 \\
\hline 5. & Litter & 29.0 & 60.44 & 0.06 \\
\hline 6. & Rice bran & 8.66 & 16.66 & 0.13 \\
\hline 7. & Rice husk & 23.33 & 40.44 & 0.16 \\
\hline 8. & Sawdust & 31.11 & 67.54 & 0.32 \\
\hline 9. & Wheatbran & 4.55 & 3.88 & 0.02 \\
\hline 10. & Control $^{\mathrm{d}}$ & 14.16 & 64.00 & 0.014 \\
\hline
\end{tabular}

*Values represented in the table are averages of results of two separately conducted experiments.

${ }^{a}$ FPase was expressed in terms of filter paper units $(\mathrm{U} / \mathrm{ml})$. One filter paper unit is defined as the amount of enzyme releasing one $\mu \mathrm{mole}$ of reducing sugar from filter paper per ml per hour.

${ }^{\mathrm{b}}$ CMCase activity was defined as amount of enzyme releasing one $\mu$ mole of reducing sugar from carboxy-methyl cellulose per ml per hour.

${ }^{\mathrm{c}} \beta$-glucosidase was defined as amount of enzyme liberating one $\mu$ mole of $\mathrm{p}$-nitrophenol per $\mathrm{ml}$ per $/ \mathrm{h}$

${ }^{\mathrm{d}}$ Czapek-Dox medium amended with $1 \%$ cellulose.

\section{DISCUSSION}

Microbial sources of cellulase enzymes are of highly great importance in the current economic value due to their versatile industrial and commercial applications. Cellulose degrading microbes are basically carbohydrate degraders and are usually incapable of using proteins and lipids as energy sources of growth. Hence, a large number of filamentous fungi, bacteria and actinomycetes produce cellulase for the fragmentation of cellulose biopolymer. The characteristic of certain fungi to secrete, abundant amounts of extracellular protein makes them most suited for the production of higher levels of extracellular cellulases. Therefore, in the present study, a cellulolytic fungus Aspergillus niger was isolated from forest litter soil and was grown under different physical and chemical conditions for the optimal production of cellulase. High titter of cellulase production was shown by Aspergillus niger at an optimal pH 5.0. Similarly, optimal growth and cellulase production by Penicillium sp. was reported at $\mathrm{pH} 5.0$ Prasanna et al. [26]. The highest activities of Endo- $\beta$-1, 4-glucanase (17.65 U/g), Exo- $\beta$-1, 4-glucanase $(13.49 \mathrm{U} / \mathrm{g})$ and $\beta$-glucosidase $(14.62 \mathrm{U} / \mathrm{g})$ were obtained at $\mathrm{pH}$ of 5.0 with sugar cane press mud by Pleurotus Sajor-Caju [27]. The maximum cellulase activity was achieved when Trichoderma viride strains were cultivated in medium set to a range of $\mathrm{pH} 5-6$; as $\mathrm{pH}$ increased up to 5.5, the hyperactivities of exoglucanase $(2.16 \mathrm{U} / \mathrm{ml})$, endoglucanase $(1.94 \mathrm{U} / \mathrm{ml})$ and $\beta$-glucosidase $(1.71 \mathrm{U} / \mathrm{ml})$ were observed [28]. Pham et al. [29] showed that the optimum $\mathrm{pH}$ for cellulases production from Aspergillus niger VTCC-F021 strain was 5.0. These reports correlate with the results of the present study. A maximum yield of cellulase was obtained at $32^{\circ} \mathrm{C}$ in this investigation. Analogous results were achieved by many workers. Gilna and Khaleel [30] reported maximum cellulase activity at $32^{\circ} \mathrm{C}$ when Aspergillus fumigatus was cultured on selected lignocellulosic wastes under liquid state fermentation. Mekala et al. [31] reported the optimum temperature for cellulase production by Trichoderma RUT C30 was $33^{\circ} \mathrm{C}$. The maximum cellulase activity was achieved at an incubation temperature of $32^{\circ} \mathrm{C}$. As the temperature was further increased, there was a gradual reduction in the enzyme production. This may be because of the fact that higher temperature denatures the enzymes and may also lead to inhibition of microbial growth [32].The temperature level of $32^{\circ} \mathrm{C}$ was proved to be the best physical factor for enzyme synthesis by Trichoderma sp. on apple pomace under solid state fermentation [33]. Bansal et al. [34] reported that $A$. niger NS-2 exhibited a wide range of temperatures for its growth and cellulase production on agriculture and kitchen waste residues. Similarly, El-Hadi et al. [35] reported that the optimum temperature for CMCase production was observed at $37^{\circ} \mathrm{C}$ for Aspergillus hortai. Among the carbon sources used in the present study, lactose was shown to be the best. This study substantiates the work of Sun et al. [33] who reported that lactose improved the cellulase production when Trichoderma sp. was grown on apple pomace under solid state fermentation while maltose and sucrose had little effect. The maximal cellulase activity $(1.18 \mathrm{U} / \mathrm{ml})$ was observed when lactose used as a carbon source for $A$. hortai [35]. Kathiresan and Manivannan [36] and Devanathan et al. [37] proved lactose as the best inducer of Aspergillus sp. Muthuvelayudham and Viruthagiri [38] reported maximum growth and cellulase enzyme production by $T$. reesei $\mathrm{C} 5$ with the provision of lactose as a sole carbon source. These reports were found to be in agreement with the results of the current study. The present study proves that supplementation of urea-induced maximum enzyme production. Identical reports were made by Jyotsna $e t$ $a l$. [39]. Urea appeared as the best nitrogen source for the highest activity of exo- $\beta$-glucanase with $4.8 \mathrm{IU} / \mathrm{ml}$, endo- $\beta$ glucanase with $5.3 \mathrm{IU} / \mathrm{ml}$ and $\beta$-glucosidase with $1.6 \mathrm{IU} / \mathrm{ml}$ by Streptomyces albaduncus. Dharmdutt and Alokkumar [40] gave a report that there was a substantial increase in the cellulase activity when the medium was supplemented 
with complex nitrogen sources like yeast extract and urea by Aspergillus flavus AT-2 and Aspergillus niger AT-3.The culture filtrate of Aspergillus niger exhibited relatively higher cellulolytic activity (1.682 U/ml) grown on Czapek-Dox medium containing $0.03 \%$ urea followed by peptone and $\mathrm{NaNO}_{3}$ [19]. These findings corroborate with the results of the present study that organic nitrogen sources such as urea and peptone served as the best compared to inorganic nitrogen sources such as $\left(\mathrm{NH}_{4}\right)_{2} \mathrm{SO}_{4}$ and $\mathrm{KNO}_{3}$. Of all the various lignocelluloses amended to the medium, sawdust supported higher yields of cellulase by Aspergillus niger. These findings were in agreement with the previous reports of Praveen Kumar et al. [41] that the wild strain of Penicillium chrysogenum PCL501 produces significant cellulase activity (100.0 $\mathrm{U} / \mathrm{ml}$ and $92.2 \mathrm{U} / \mathrm{ml}$ ) and extracellular proteins when sawdust was used as the sole carbon source. The highest amount of cellulase activity was exhibited by Aspergillus niger followed by Trichoderma viride by solid-state fermentation with sawdust as a substrate [42]. Supplementation of sawdust at $1 \%$ level resulted in higher activities of FPase (2.412 U/ml), CMCase $(0.775 \mathrm{U} / \mathrm{ml})$ and $\beta$-glucosidase $(1.322 \mathrm{U} / \mathrm{ml})$ by Aspergillus niger [19].

\section{CONCLUSION}

The potent cellulolytic fungi, Aspergillus niger was grown in Czapek-Dox medium under optimal physical and chemical conditions. A temperature of $32^{\circ} \mathrm{C}$ and $\mathrm{pH}$ value of 5.0 were found to be the optimal condition for cellulase production. Among various carbon and nitrogen sources tested in this study, lactose and urea yielded peak values of cellulase. Natural lignocellulosic materials like sawdust and forest litter served as good substrates for enhanced production of cellulase.

\section{ETHICS APPROVAL AND CONSENT TO PARTICIPATE}

Not applicable.

\section{HUMAN AND ANIMAL RIGHTS}

No animals/humans were used for studies that are the basis of this research.

\section{CONSENT FOR PUBLICATION}

Not applicable.

\section{CONFLICT OF INTEREST}

The authors declare no conflict of interest, financial or otherwise.

\section{ACKNOWLEDGEMENTS}

The first author was highly thankful to Prof. D.V.R. Sai Gopal, Department of Virology, and S.V. University for providing laboratory facility for carrying out this work.

\section{REFERENCES}

[1] Brijwani K, Oberoi HS, Vadlani PV. Production of cellulolytic enzyme system in mixed culture solid-state fermentation of soybean hulls supplemented with wheat bran. Process Biochem 2010; 45: 120-8. [http://dx.doi.org/10.4061/2011/860134]. [http://dx.doi.org/10.1016/j.procbio.2009.08.015]

[2] Ram L, Kuldeep K, Sandeep S. Screening isolation and characterization of cellulase producing microorganisms from soil. Int J PharmSci Invent 2014; 3(3): 12-8.

[3] Jagtap S, Rao M. Purification and properties of a low molecular weight 1,4-beta-d-glucan glucohydrolase having one active site for carboxymethyl cellulose and xylan from an alkalothermophilic Thermomonospora sp. Biochem Biophys Res Commun 2005; 329(1): 111-6. [http://dx.doi.org/10.1016/j.bbrc.2005.01.102] [PMID: 15721281]

[4] Bhat MK. Cellulases and related enzymes in biotechnology. Biotechnol Adv 2000; 18(5): 355-83. [http://dx.doi.org/10.1016/S0734-9750(00)00041-0] [PMID: 14538100]

[5] Kim KC, Seung-Soo Y, Oh Young A, Seong-Jun K. Isolation and characterization of Trichoderma harzianum FJ1 producing cellulase and xylanase. J Microbiol Biotechnol 2003; 13: 1-8.

[6] Mahro B, Timm M. Potential of bio-waste from the food industry as a biomass resource. Eng Life Sci 2007; 7: 457-68. [http://dx.doi.org/10.1002/elsc.200620206]

[7] Abd-Elzaher FH, Fadel M. Production of bioethanol via enzymatic saccharification of rice straw by cellulase produced by Trichoderma reesei under solid state fermentation. Int J Appl Microbiol Biotechnol Res 2010; 43(3): 72-8.

[8] Amir I, Zahid A, Yusuf Z, et al. Optimization of cellulase enzyme production from corn cobs using Alternaria alternata by solid state 
fermentation. J Cell Mol Biol 2011; 9(2): 51-6.

[9] Nevalainen H, Penttila M. Kuck U. Molecular Biology of Cellulolytic Fungi. In: Berlin, Heidelberg: Springer Verlag: The Mycota, Vol. II, Genetics and Biotechnology 2003; pp. 303-19.

[10] Shimosaka M, Kumehara M, Zhang XY, et al. Cloning and characterization of a chitosanase gene from the plant pathogenic fungus Fusarium solani. J Ferment Bioeng 1996; 82: 426-31. [http://dx.doi.org/10.1016/S0922-338X(97)86977-2]

[11] Ariunaa J, Temuulen G. Distribution of Cellulolytic Fungi in Soil of Mongolia. Scientific Journal "Biology" Mongolian National University, 2001, 10, 71-3.

[12] Chand P, Aruna A, Maqsood A M, Rao LV. Novel mutation method for increased cellulase production. J Appl Microbiol 2005; 98(2): 318-23.

[13] Pandey A, Soccol CR, Poonam Nigam P, Saccol VT. Biotechnological potential of agro-Industrial residues.1: Sugarcane bagasse. Bioresour Technol 2000; 7(1): 69-80. [http://dx.doi.org/10.1016/S0960-8524(99)00142-X]

[14] Duff SJB, Murray WD. Bioconversion of forest products and industry waste cellulosics to fuel ethanol: A review. Bioresour Technol 1996; 55: $1-33$.

[http://dx.doi.org/10.1016/0960-8524(95)00122-0]

[15] Nieves RA, Ehrman CL, Adney WS, Elander RT, Himmel ME. Technical communication: Survey and analysis of commercial cellulase preparations suitable for biomass conversion to ethanol. World J Microbiol Biotechnol 1998; 14: 301-4. [http://dx.doi.org/10.1023/A:1008871205580]

[16] Chahal PS, Chahal DS, Andre G. Cellulase production profile of Trichoderma reesei on different cellulosic substrates at various pH levels'. Ferment Bioeng 1992; 74: 126-8.

[http://dx.doi.org/10.1016/0922-338X(92)80015-B]

[17] Reczey K, Szengyel Z, Eklund RC, Zacchi G. Cellulase production by T. reesei. Bioresour Technol 1996; 57: 25-30. [http://dx.doi.org/10.1016/0960-8524(96)00038-7]

[18] Srilakshmi A, Narasimha G. Production of cellulases by fungal cultures isolated from forest litter soil. Ann For Res 2012; 55(1): 85-92.

[19] Narasimha G, Sridevi A, Viswanath B, Subhosh Chandra M, Rajasekhar Reddy B. Nutrient effects on production of cellulolytic enzymes by Aspergillus niger. Afr J Biotechnol 2006; 5(5): 472-6.

[20] Lowry OH, Rosebrough NJ, Farr AL, Randall RJ. Protein measurement with the folin phenol reagent. J Biol Chem 1951; $193(1)$ : 265-75. [PMID: 14907713]

[21] Miller GL. Use of dinitrosalicylic acid reagent for determination of reducing sugars. Anal Chem 1959; 31: 426-9. [DOI: 10.1021/ac60147a030].

[http://dx.doi.org/10.1021/ac60147a030]

[22] Mandels M, Weber J. Cellulases and its application. In: Am Chem Soc. Washington, DC: Advances in chemistry Series (R.F. Gould. Ed) 1969; 95: pp. 391-414.

[23] Ghosh TK. Measurement of cellulase activities. Pure Appl Chem 1987; 59(2): 257-68. [http://dx.doi.org/10.1351/pac198759020257]. [http://dx.doi.org/10.1351/pac198759020257]

[24] Herr D. Secretion of cellulase and beta-glucosidase by Trichoderma viride ITCC-1433 in submerged culture on different substrates. Biotechnol Bioeng 1979; 21(8): 1361-71. [DOI: 10.1002/bit.260210805]. [PMID: 110377]. [http://dx.doi.org/10.1002/bit.260210805] [PMID: 110377]

[25] Narasimha G, Babu GVAK, Rajasekhar Reddy B. Cellulolytic activity of fungal cultures isolated from soil contaminated with effluents of cotton ginning industry. J Sci Ind Res (India) 1998; 57: 617-20.

[26] Prasanna HN, Ramanjaneyulu G, Rajasekhar Reddy B. Optimization of cellulase production by Penicillium sp. 3 Biotech. 2016 ; 6: 162.

[27] Pandit Nitin Prakash, Maheshwari Sanjiv Kumar. Optimization of cellulase enzyme production from sugarcane Press mud using oyster mushroom - pleurotus sajor-Caju by solid state fermentation. J Bioremediat Biodegrad 2012; 3(3): 1-5.

[28] Gautam SP, Bundela PS, Pandey AK, Awasthi MK, Sarsaiya S. Screening of cellulolytic fungi for management of municipal solid waste. J Appl Sci in Environ Sanita 2010; 4(3): 391-5.

[29] Pham TH, Quyen DT, Nghiem NM. Optimization of endoglucanase production by Aspergillus niger VTCCF021. Aust J Basic Appl Sci 2010; 4(9): 4151-7.

[30] Gilna VV, Khaleel KM. Biochemistry of cellulase enzyme activity of Aspergillus fumigatus from mangrove soil on lignocellulosics substrate. Recent ResSciTechnol 2011;3(1): 132-4.

[31] Mekala NK, Singhania RR, Sukumaran RK, Pandey A. Cellulase production under solid-state fermentation by Trichoderma reesei RUT C30: Statistical optimization of process parameters. Appl Biochem Biotechnol 2008; 151(2-3): 122-31. [http://dx.doi.org/10.1007/s12010-008-8156-9] [PMID: 18975142]

[32] Shazia KM, Hamid M, Ammad AF, Haq IU. Optimization of process parameters for the biosynthesis of cellulose by Trichoderma viride. Pak J Bot 2010; 42(6): 4243-51. 
[33] Sun H, Xiangyang Ge, ZhikuiHao Ming P. Cellulase production by Trichoderma sp. on apple pomace under solid state fermentation. Afr J Biotechnol 2010; 9(2): 163-6. [DOI: 10.4314/ajb.v9i2.].

[34] Bansal N, Tewari R, Soni R, Soni SK. Production of cellulases from Aspergillus niger NS-2 in solid state fermentation on agricultural and kitchen waste residues. Waste Manag 2012; 32(7): 1341-6.

[http://dx.doi.org/10.1016/j.wasman.2012.03.006] [PMID: 22503148]

[35] El-Hadi A. Anwar.optimization of cultural and nutritional conditions for carboxymethylcellulase production by Aspergillus hortai. J Radiat Res Appl Sci 2014; 7(23): 28-F36.

[36] Kathiresan K, Manivannan S. Cellulase production by Penicillium fellutanum isolated from coastal mangrove rhizosphere soil. Res J Microbial 2006; 1(5): 438-42. [http://dx.doi.org/10.3923/jm.2006.438.442]. [http://dx.doi.org/10.3923/jm.2006.438.442]

[37] Devanathan G, Shanmugan A, Balasubramanian T, et al. Cellulase production by Aspergillus niger isolated from coastal mangrove debris. Trends Appl Sci Res 2007; 2: 23-7. [http://dx.doi.org/10.3923/tasr.2007.23.27]. [http://dx.doi.org/10.3923/tasr.2007.23.27]

[38] Muthuvelayudham R, Viruthagiri T. Fermentative production and kinetics of cellulase protein on Trichoderma reesei using sugarcane bagasse and rice straw. Afr J Biotechnol 2006; 5(20): 1873-81.

[39] Jyotsna PK, Ramakrishna Rao A, Devaki K. Effect of nutritional factors on cellulase production by Streptomyces albaduncus from the gut of earthworm, Eiseniafoetida. Pest Manage Hortic Ecosyst 2015; 21(1): 75-80.

[40] Dharm Dutt and AlokAumar. Optimization of cellulase production under solid-state fermentation by Aspergillus flavus (AT-2) and Aspergillus niger (AT-3) and its impact on stickies and ink particle size of sorted office paper. Cellulose ChemTechnol 2014; 48(3-4): 285-98.

[41] Praveen Kumar Reddy G, Narasimha G, Dileep Kumar K, et al. Cellulase production by Aspergillus niger on different natural lignocellulosic substrates. Int J Curr Microbial Appl Sci 2014; 4(1): 835-45.

[42] Bhoos Reddy GL. Comparative study of cellulase production by Aspergillus niger and Trichoderma viride using solid state fermentation on cellulosic substrates corncob, cane bagasse and sawdust. Int J Sci Res (Ahmedabad) 2014; 3(5): 324-6.

(C) 2018 Akula and Golla.

This is an open access article distributed under the terms of the Creative Commons Attribution 4.0 International Public License (CC-BY 4.0), a copy of which is available at: (https:/creativecommons.org/licenses/by/4.0/legalcode). This license permits unrestricted use, distribution, and reproduction in any medium, provided the original author and source are credited. 